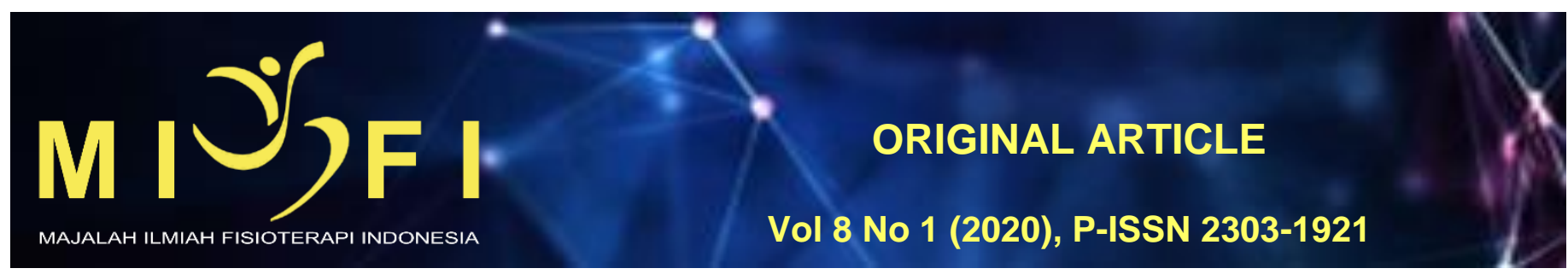

\title{
HUBUNGAN INDEKS MASSA TUBUH, PERSENTASE LEMAK TOTAL TUBUH, DAN AKTIVITAS FISIK TERHADAP TINGKAT VOLUME OKSIGEN MAKSIMAL PADA REMAJA PUTRI DI DENPASAR SELATAN
}

\author{
Kadek Dwi Pradnya Lestari ${ }^{1}$, Nila Wahyuni ${ }^{2}$, Made Hendra satria Nugraha ${ }^{3}$, Ni Wayan Tianing ${ }^{4}$ \\ ${ }_{1}^{1}$ Program Studi Sarjana Fisioterapi dan Profesi Fisioterapi, Fakultas Kedokteran Universitas Udayana \\ 2Dapartemen Ilmu Faal, Fakultas Kedokteran Universitas Udayana \\ ‘3Departemen Fisioterapi, Fakultas Kedokteran Universitas Udayana \\ ${ }^{4}$ Departemen Biokimia, Fakultas Kedokteran Universitas Udayana \\ dwilestari2397@gmail.com
}

\begin{abstract}
ABSTRAK
$\mathrm{VO}_{2}$ maks adalah jumlah oksigen maksimal yang dapat dikonsumsi oleh tubuh. Penurunan $\mathrm{VO}_{2}$ maks dapat memperburuk prognosis penyakit degeneratif. $\mathrm{VO}_{2}$ maks dipengaruhi oleh beberapa faktor seperti aktivitas fisik, IMT, dan persentase lemak total tubuh. Penelitian ini bertujuan mengetahui hubungan keseluruhan antara indeks massa tubuh, persentase lemak total tubuh, dan aktivitas fisik terhadap tingkat volume oksigen maksimal pada remaja putri di Denpasar Selatan Penelitian ini merupakan penelitian observasional dengan cross sectional analysis pada 61 remaja putri di SMAN 2 Denpasar usia 15-17 tahun. Pengambilan sampel menggunakan teknik purposive sampling. Uji hipotesis dalam penelitian ini menggunakan uji spearman rank, dan pearson untuk uji bivariat dan regresi linier ganda pada uji multivariat. Hasil dari penelitian ini didapat hubungan antara IMT dengan persentase lemak total tubuh dengan $r=0,882 ; p=0,000$. Hubungan bermakna antara IMT dengan $V_{2}$ maks dengan $r=-0,883 ; p=0,000$. Hubungan bermakna antara persentase lemak total tubuh dengan $\mathrm{VO}_{2}$ maks dengan $r=-0,987 ; p=0,000$. Hubungan bermakna antara aktivitas fisik dengan $\mathrm{VO}_{2}$ maks dengan $r=0,851 ; p=0,000$. Hubungan bermakna antara aktivitas fisik dengan IMT dengan $r=-$ 0,$817 ; p=0,000$. Hubungan bermakna antara aktivitas fisik dengan persentase lemak $r=0,850 ; p=0,000$. Terdapat hubungan antara IMT, persentase lemak total tubuh dan aktivitas fisik dengan VO2 maks dengan $F_{\text {hitung }}>F_{\text {tabel }}(1907,382$ $>2,79)$. Kesimpulan dalam penelitian ini yaitu IMT,persentase lemak total tubuh dan aktivitas fisik sama- sama memiliki hubungan yang sangat kuat dan bermakna dengan $\mathrm{VO}_{2}$ maks.
\end{abstract}

Kata Kunci: remaja putri, vo2 maks, aktivitas fisik, imt, persentase lemak total tubuh

\section{RELATIONSHIP OF BODY MASS INDEX, TOTAL BODY FAT PERCENTAGE, AND PHYSICAL ACTIVITY TOWARDS LEVEL OF MAXIMUM OXYGEN IN FEMALE ADOLESCENTS AT SOUTH DENPASAR}

\begin{abstract}
$\mathrm{VO}_{2}$ max is the amount of maximum oxygen that can be consumed by the body. Decreasing $\mathrm{VO}_{2} \max$ can worsen the prognosis of degenerative diseases. $\mathrm{VO}_{2}$ max is influenced by several factors such as physical activity, $\mathrm{BMI}$, and total body fat percentage. The research aims to determine the overall relationship between BMI, total body fat percentage, and physical activity toward the $\mathrm{VO}_{2}$ max level in female adolescents at South Denpasar. This study was observational with a cross-sectional analysis of 61 female adolescents in SMAN 2 Denpasar aged 15-17 years. Sampling was done by purposive sampling. The hypothesis test used was spearman's rank and pearson for bivariate correlation and linear regression for multivariate. The results of this study found a significant relationship between $\mathrm{BMI}$ and total body fat percentage with $r=0.882 ; p=0,000$. The significant relationship found between $\mathrm{BMI}$ and $\mathrm{VO}_{2} \max$ with $r=-0.883 ; p=0,000$. Total body fat percentage and $V_{2}$ max found $r=-0.984 ; p=0.000$ which means a significant relationship. $r=0.851 ; p=0.000$ for correlation between $\mathrm{VO}_{2}$ max and physical activity that means a significant relationship. Besides that study found a significant relationship for physical activity and BMI with $r=-0.817 ; p=0.000$, and a relationship between physical activity and total body fat percentage $r=0.850 ; p=0.000$. There was a relationship between BMI, total body fat percentage and physical activity with $\mathrm{VO}_{2}$ max with $\mathrm{Fcount}>\mathrm{Ftable}(1907,382>2.79)$. The conclusions of this study showed that BMI, total body fat percentage and physical activity both had a strong and significant relationship toward $\mathrm{VO}_{2}$ max.
\end{abstract}

Keywords: female adolescents, vo2 max, physical activity, bmi, total body fat percentage 


\section{PENDAHULUAN}

$\mathrm{VO}_{2}$ maks adalah jumlah oksigen maksimum yang dapat dikonsumsi oleh tubuh dan juga paling sering digunakan untuk mengukur transportasi oksigen serta kapasitas kardiorespirasi individu pada tingkat tertentu. ${ }^{[1][2]}$ Keteyian, et al. (2008) melaporkan bahwa penurunan $\mathrm{VO}_{2}$ maks dapat memperburuk prognosis penyakit degeneratif seperti diabetes militus tipe 2 dan penyakit kardiovaskular. Berdasarkan statistik dunia terdapat 9,4 juta kematian pertahun yang disebabkan oleh penyakit kardiovaskuler dan diperkirakan akan meningkat hingga 23,3 juta pada tahun 2030. Menurut Riset Kesehatan dasar tahun 2013 bahwa rata-rata penderita penyakit jantung, gagal jantung, dan diabetes militus tipe 2 lebih banyak dialami oleh perempuan dibandingkan laki-laki dengan perbedaan $21.5 \%$, ${ }^{[4]}$ sehingga dengan penurunan $\mathrm{VO}_{2}$ maks pada perempuan sekitar $12.5 \mathrm{~mL} / \mathrm{kg} /$ menit beresiko meningkatkan kematian dibandingkan laki-laki dengan penurunan $\mathrm{VO}_{2}$ maks kisaran $19 \mathrm{~mL} / \mathrm{kg} /$ menit dari batas normal. ${ }^{[3]}$

Penurunan $\mathrm{VO}_{2}$ maks juga akan berdampak terhadap kualitas hidup seseorang..$^{[5]} \mathrm{Hal}$ tersebut didukung oleh penelitian Scribbans (2016) yang menyatakan bahwa adanya aktivitas fisik menyebabkan peningkatan satu equivalen $\mathrm{VO}_{2}$ maks dan akan meningkatkan 10-25\% kelangsungan hidup individu. Menurut Christou, et.al. (2005) dalam ${ }^{[8]}$ wanita dengan $\mathrm{VO}_{2}$ maks rendah memiliki risiko lebih besar mengalami kematian, dimana rata-rata $\mathrm{VO}_{2}$ maks pada wanita sehat dan aktif sekitar $29 \mathrm{~mL} / \mathrm{kg} /$ menit sementara pada pria sehat dan aktif sekitar $38 \mathrm{~mL} / \mathrm{kg} / \mathrm{menit}$, sedangkan pada penelitian Strijk, et al. (2010) melaporkan bahwa pada usia 8-16 tahun terjadi peningkatan $\mathrm{VO}_{2}$ maks secara progresif dan pada usia lebih dari 25 tahun dengan gaya hidup sedentari $\mathrm{VO}_{2}$ maks mengalami penurunan secara bertahap (1 $\%$ per tahun) serta $\mathrm{VO}_{2}$ maks mengalami penurunan $0,5 \%$ per tahun pada orang yang masih aktif secara fisik. ${ }^{[10]}$

Gim dan Junghyun (2016) melaporkan bahwa aktivitas fisik berperan terhadap perubahan $\mathrm{VO}_{2}$ maks. Menurut Riset Kesehatan Dasar Kementerian Kesehatan Indonesia tahun 2007 terdapat 48,2\% masyarakat pada usia lebih dari 10 tahun mengalami penurunan aktivitas fisik yang berdampak terhadap kemampuan ambilan oksigen ${ }^{[12][13]}$. Berdasarkan penelitian yang dilakukan oleh Murbawani (2017) ditemukan bahwa terdapat hubungan yang bermakna antara aktivitas fisik terhadap $\mathrm{VO}_{2}$ maks, dimana rata-rata remaja putri dengan aktivitas fisik rendah memiliki $\mathrm{VO}_{2}$ maks yang rendah. Aktivitas fisik yang rendah menyebabkan menurunnya kebutuhan energi ke jaringan sehingga mengakibatkan berukurangnya $\mathrm{VO}_{2}$ maks yang diikuti dengan meningkatnya kelelahan. ${ }^{15]}$

Faktor yang juga ikut mempengaruhi $\mathrm{VO}_{2}$ maks adalah IMT. Pada penelitian Alamsyah, et al. (2017) diketahui adanya korelasi negatif yang signifikan antara IMT dengan $\mathrm{VO}_{2}$ maks, dimana pada seseorang dengan IMT besar akan menyebabkan penurunan ambilan oksigen sehingga memiliki risiko tinggi mengalami penyakit degeneratif dibandingkan seseorang dengan IMT normal. Hal tersebut karena pada obesitas terdapat peningkatan serat otot tipe II dan penurunan serat otot tipe I yang memiliki efek penting terhadap berkurangnya $\mathrm{VO}_{2}$ maks. ${ }^{[15]}$

Penurunan $\mathrm{VO}_{2}$ maks juga disebabkan oleh peningkatan persentase lemak total tubuh.[16] Remaja putri cenderung memiliki massa lemak total tubuh yang lebih tinggi dibandingkan remaja putra. ${ }^{[17]}$ Berdasarkan penelitian yang dilakukan oleh Murbawani (2017) bahwa terdapat hubungan negatif yang bermakna antara persentase lemak total tubuh terhadap $\mathrm{VO}_{2}$ maks, dimana remaja dengan persentase lemak total tubuh yang tinggi memiliki $\mathrm{VO}_{2}$ maks yang lebih rendah ${ }^{[5]}$. Hal tersebut terjadi akibat sejumlah besar lemak tubuh memberikan beban yang tidak baik pada fungsi pernapasan jantung yang mengakibatkan berkurangnya ambilan oksigen oleh otot-otot kerja yang aktif.[5] Berdasarkan latar belakang berikut dirasa penting untuk melakukan penelitian lebih lanjut mengenai "hubungan indeks massa tubuh, persentase lemak total tubuh dan aktivitas fisik terhadap tingkat $\mathrm{VO}_{2}$ max pada remaja putri di Denpasar Selatan"

\section{METODE}

Penelitian ini merupakan penelitian observasional dengan cross-sectional analysis yang dilakukan di SMAN 2 Denpasar pada bulan Maret-April 2019. Kriteria inklusi pada penelitian ini adalah berjenis kelamin perempuan, berusia 15-17 tahun, suhu badan normal $\left(36,5^{\circ} \mathrm{C}-37,5^{\circ} \mathrm{C}\right)$, dan bersedia menjadi sampel penelitian. Kriteria ekslusi pada penelitian ini adalah sakit saat dilakukan penelitian, memiliki riwayat anemia, asma, dan merokok, penggunaan obatobatan yang dapat mempengaruhi $\mathrm{VO}_{2}$ maks seperti obat golongan glukokortikoid (betamethasone, budesonide, dexamethasone, predisone, dan prednisolone). Variabel bebas dalam penelitian ini adalah indeks,massa tubuh, persentase lemak total tubuh, dan aktivitas fisik. Variabel terikat dalam penelitian ini adalah Volume oksigen maksimal. Sampel diambil dengan cara purposive sampling dan diperoleh sebesar 61 sampel. Pengambilan data dilakukan dengan cara mengukur tinggi badan, berat badan, melihat umur dan jenis kelamin kemudian dihitung dengan menggunakan percentil untuk mengetahui IMT, pengukuran persentase lemak total tubuh dengan BIA, pengukuran aktivitas fisik dengan kuisioner IPAQ-SF, dan $\mathrm{VO}_{2}$ maks dengan Harvard step test. Data yang diperoleh dari pengukuran tersebut kemudian dilakukan uji univariat untuk mengetahui frekuensi, rata-rata dan standar deviasi masing-masing variabel, dilanjutkan uji normalitas data numerik, kemudian uji bivariat dimana dilakukan uji spearman's rank dan pearson, dan terakhir dilakukan uji multivariat regresi linier ganda terhadap faktor-faktor yang mempengaruhi $\mathrm{VO}_{2} \mathrm{maks}$.

\section{HASIL}

Tabel 1 Karakteristik Responden Berdasarkan Usia, IMT, Persentase Lemak Total Tubuh, Aktivitas Fisik dan $\mathrm{VO}_{2}$ Maks

\begin{tabular}{lc}
\hline \multicolumn{1}{c}{ Variabel } & $\mathbf{N}(\%)$ \\
\hline Usia & \\
15 & $4(6,6 \%)$ \\
16 & $31(50,8 \%)$ \\
17 & $26(42,6 \%)$ \\
IMT & \\
Underweight & $4(6,6 \%)$ \\
Normal & $40(65,6 \%)$
\end{tabular}




\begin{tabular}{lc}
$\begin{array}{l}\text { Overweight } \\
\text { Obese } \\
\text { \%Lemak Total Tubuh }\end{array}$ & $10(16,5 \%)$ \\
Low & $7(11,5 \%)$ \\
Normal & $13(21,3 \%)$ \\
Slight High & $31(50,8 \%)$ \\
High & $12(19,7 \%)$ \\
Aktivitas Fisik & $5(8,2 \%)$ \\
Rendah & \\
Sedang & $17(27,9 \%)$ \\
Berat $_{\text {VO }_{2} \text { Maks }}$ & $17(27,9 \%)$ \\
Buruk & $27(44,3 \%)$ \\
Sedang & \\
Baik & $17(27,9 \%)$ \\
\hline
\end{tabular}

Tabel 2 Karakteristik Responden Berdasarkan Usia, IMT,

Persentase Lemak Total Tubuh, Aktivitas Fisik dan $\mathrm{VO}_{2}$ Maks

\begin{tabular}{ccc}
\hline Variabel & Rerata \pm SD & $\boldsymbol{p}$ \\
\hline Usia & $16,361 \pm 0,606$ & 0,000 \\
IMT & $55,039 \pm 30,391$ & 0,05 \\
\% Lemak Total Tubuh & $26,689 \pm 6,354$ & 0,200 \\
Aktivitas Fisik & $2326,370 \pm 1605,407$ & 0,003 \\
VO $_{2}$ Maks & $60,509 \pm 16,062$ & 0,200 \\
\hline
\end{tabular}

Pada tabel diatas responden terbanyak pada usia 16 tahun yaitu 31 orang atau sebanyak $50,8 \%$ dengan ratarata 16,361, standar deviasi sebesar 0,606 dan nilai $p=0,000(p<0,05)$ yang diinterpretasikan data tidak berdistribusi normal. Pada tabel IMT terlihat bahwa rata-rata IMT adalah 55,039 percentil yang termasuk dalam kategori normal dengan standar deviasi 30,931 serta nilai $p=0,05$ yang diinterpretasikan data tidak berdistribusi normal. Pada hasil penelitian tersebut juga terlihat bahwa paling banyak remaja putri berada pada IMT kategori normal yaitu 40 orang dengan frekuensi $65.6 \%$. Pada tabel persentase lemak total tubuh rata-rata lemak total remaja putri yaitu $26,689 \%$ yang termasuk dalam kategori normal dengan standar deviasi 6,354 serta nilai $p>0,05(p=0,200)$ yang diinterpretasikan data berdistribusi normal. Pada hasil penelitian tersebut juga terlihat bahwa paling banyak remaja putri berada pada kategori normal yaitu 31 orang dengan frekuensi 50.8\%. Rata-rata aktivitas fisik pada remaja putri yaitu 2326,370 MET yang termasuk dalam kategori aktivitas fisik sedang dengan standar deviasi 1605,407 serta nilai $p<0,05(0,003)$ yang diinterpretasikan data tidak berdistribusi normal. Pada hasil penelitian tersebut juga terlihat bahwa paling banyak remaja putri berada pada kategori aktivitas fisik berat yaitu 27 orang dengan frekuensi $44,3 \%$. Rata-rata $\mathrm{VO}_{2} \mathrm{Maks}$ remaja putri yaitu $60,056 \mathrm{ml} /$ menit/kg yang termasuk dalam kategori $\mathrm{VO}_{2}$ maks sedang dengan standar deviasi 16,062 serta nilai $p>0,05(p=0,200)$ yang diinterpretasikan data berdistribusi normal. Pada hasil penelitian tersebut juga terlihat bahwa paling banyak remaja putri memiliki $\mathrm{VO}_{2}$ Maks kategori sedang yaitu 32 orang dengan frekuensi $52,5 \%$

Tabel 3 Hubungan Indeks Massa Tubuh terhadap Persentase Lemak Total Tubuh dengan menggunakan Analisis Non Parametrik Spearman's Rank

\begin{tabular}{ccc}
\hline Korelasi Variabel & $\mathbf{r}$ & $\mathbf{p}$ \\
\hline IMT dengan \% Lemak Total Tubuh & 0,882 & 0,000 \\
\hline
\end{tabular}

Berdasarkan tabel 3 menunjukan bahwa terdapat hubungan yang sangat kuat, signifikan, dan searah antara IMT dengan persentase lemak total tubuh pada remaja putri yaitu semakin tinggi IMT seseorang maka semakin tinggi persentase lemak total tubuh dengan $(p<0,05)$ dan $r=0,882$. Koefisien determinasi yang diberikan oleh IMT terhadap persentase lemak total tubuh yaitu $77,79 \%$ sedangkan sisanya $22.21 \%$ dipengaruhi oleh variabel yang tidak diketahui.

Tabel 4 Hubungan IMT dengan $\mathrm{VO}_{2}$ Maks

terhadap Analisis Non Parametrik Spearman's Rank

\begin{tabular}{ccc}
\hline Korelasi Variabel & $\mathbf{r}$ & $\mathbf{p}$ \\
\hline IMT dengan $\mathrm{VO}_{2}$ Maks & $-0,883$ & 0,000 \\
\hline
\end{tabular}

Berdasarkan tabel 4 menunjukan bahwa terdapat hubungan yang sangat kuat, signifikan, dan berlawanan arah antara IMT dengan $\mathrm{VO}_{2}$ maks pada remaja putri yaitu semakin tinggi IMT seseorang maka semakin rendah $\mathrm{VO}_{2}$ maks dengan $(p<0,05)$ dan $r=-0,883$. Koefisien determinasi yang diberikan oleh IMT terhadap $\mathrm{VO}_{2}$ maks $77,98 \%$ sedangkan sisanya $22.02 \%$ dipengaruhi oleh variabel yang tidak diketahui.

Tabel 5 Hubungan Persentase Lemak Total Tubuh terhadap $\mathrm{VO}_{2}$ Maks dengan Analisis parametric Pearson

\begin{tabular}{ccc}
\hline Korelasi Variabel & $\mathbf{r}$ & $\mathbf{p}$ \\
\hline$\%$ Lemak Total Tubuh dengan $\mathrm{VO}_{2}$ Maks & $-0,984$ & 0,000 \\
\hline
\end{tabular}

Berdasarkan Tabel 5 menunjukan bahwa terdapat hubungan hubungan yang sangat kuat, signifikan dan berlawanan arah antara persentase lemak total tubuh dengan $\mathrm{VO}_{2}$ maks pada remaja putri yaitu semakin tinggi persentase lemak total tubuh seseorang maka semakin rendah $\mathrm{VO}_{2}$ maks dengan $(p<0,05)$ dan $r=-0,984$. Koefisien 
determinasi yang diberikan oleh persentase lemak total tubuh terhadap $\mathrm{VO}_{2}$ maks yaitu sebesar $96,82 \%$ sedangkan sisanya $3,18 \%$ dipengaruhi oleh variabel yang tidak diketahui.

Tabel 6 Hubungan Aktivitas Fisik terhadap $\mathrm{VO}_{2}$ Maks dengan analisis non parametrik Spearman's Rank

\begin{tabular}{ccc} 
Korelasi Variabel & $\mathbf{r}$ & $\mathbf{p}$ \\
\hline tas Fisik dengan $\mathrm{VO}_{2}$ Maks & 0,851 & 0,000 \\
\hline
\end{tabular}

Berdasarkan tabel 6 menunjukan bahwa terdapat hubungan yang sangat kuat, signifikan, dan searah antara aktivitas fisik dengan $\mathrm{VO}_{2}$ maks pada remaja putri yaitu semakin tinggi aktivitas fisik seseorang maka semakin tinggi $\mathrm{VO}_{2}$ maks dengan $(\mathrm{p}<0,05)$ dan $\mathrm{r}=0,851$. Koefisien determinasi yang diberikan oleh aktivitas fisik terhadap $\mathrm{VO}_{2}$ maks yaitu sebesar $\mathrm{KD}=72,42 \%$ sedangkan sisanya $27.58 \%$ dipengaruhi oleh variabel yang tidak diketahui.

Tabel 7 Hubungan Aktivitas Fisik terhadap IMT dengan analisis non parametrik Spearman's Rank

\begin{tabular}{ccc}
\hline Korelasi Variabel & $\mathbf{r}$ & $\mathbf{p}$ \\
\hline Aktivitas fisik dengan IMT & $-0,817$ & 0,000 \\
\hline
\end{tabular}

Berdasarkan tabel 7 menunjukan bahwa terdapat hubungan yang sangat kuat, signifikan, dan berlawanan arah antara aktivitas fisik dengan IMT pada remaja putri yaitu semakin tinggi aktivitas fisik seseorang maka semakin rendah IMT dengan $(p<0,05)$ dan $r=0,817$. Koefisien determinasi yang diberikan oleh aktivitas fisik terhadap IMT yaitu sebesar $66,74 \%$ sedangkan sisanya $33.26 \%$ dipengaruhi oleh variabel yang tidak diketahui.

Tabel 8 Hubungan Aktivitas Fisik terhadap Persentase Lemak Total Tubuh dengan Analisis Non Parametrik Spearman's Rank

\begin{tabular}{ccc}
\hline Korelasi Variabel & $\mathbf{r}$ & $\mathbf{p}$ \\
\hline Aktivitas fisik dengan Persentase Lemak Total Tubuh & $-0,850$ & 0,000 \\
\hline
\end{tabular}

Pada tabel 8 menunjukan bahwa terdapat hubungan hubungan yang sangat kuat, signifikan, dan berlawanan antara aktivitas fisik dengan persentase lemak total tubuh yaitu semakin tinggi aktivitas fisik seseorang maka semakin rendah persentase lemak total tubuh dengan $(p<0,05)$ dan $r=-0,850$. Koefisien determinasi yang diberikan oleh aktivitas fisik terhadap persentase lemak total tubuh yaitu sebesar $72,25 \%$ sedangkan sisanya $27.75 \%$ dipengaruhi oleh variabel yang tidak diketahui.

Tabel 9 Hubungan IMT, Persetase Lemak Total Tubuh dan Aktivitas Fisik terhadap Tingak VO2 Maks dengan Analisis Multivariat Regresi Linier Ganda

\begin{tabular}{lccc}
\hline Regresi Variabel & $r$ & $F_{\text {hitung }}$ & $F_{\text {tabel }}$ \\
\hline IMT, \% Lemak Total Tubuh & & & \\
dan Aktivitas fisik terhadap & 0,995 & 1907,282 & 2,79 \\
VO2 Maks & & & 0,000 \\
\hline
\end{tabular}

a.Variabel Dependen: $\mathrm{VO}_{2}$ Maks

Berdasarkan Tabel 9 menunjukan bahwa terdapat hubungan antara IMT, persentase lemak total tubuh, dan aktivitas fisik terhadap tingkat $\mathrm{VO}_{2}$ maks dengan $F_{\text {hitung }}>F_{\text {tabel }}(1907,382>2,79)$ atau $p<0,05$. Korelasi $(R)$ yang secara simultan (bersama-sama) antara variabel IMT, persentase lemak total tubuh, dan aktivitas fisik terhadap $\mathrm{O}_{2}$ maks diperoleh nilai sebesar 0,995. Koefisien determinasi yang diberikan oleh kedua variabel bebas terhadap variabel terikat yaitu sebesar $99 \%$ sedangkan sisanya $1 \%$ dipengaruhi oleh variabel lain.

Tabel 10 Hasil Analisis Multivariat Indeks Massa Tubuh,

\begin{tabular}{|c|c|c|c|c|c|}
\hline Variabel & B & SE & $\mathbf{T}_{\text {hitung }}$ & p & $\mathbf{T}_{\text {tabel }}$ \\
\hline IMT & $-0,134$ & 0,055 & $-2,429$ & 0,018 & \\
\hline \% Lemak Total Tubuh & $-1,163$ & 0,134 & $-8,691$ & 0,000 & 2,002 \\
\hline Aktivitas Fisik & 0,003 & 0,001 & 3,333 & 0,002 & \\
\hline
\end{tabular}

a.Variabel Dependen: $\mathrm{VO}_{2}$ Maks

Berdasarkan Tabel 10 menunjukan bahwa IMT, persentase lemak total tubuh dan aktivitas fisik dapat memprediksi tingkat $\mathrm{VO}_{2}$ maks, dimana peningkatan $1 \mathrm{ml} / \mathrm{menit} / \mathrm{kg} \mathrm{VO}$ maks akan menurunkan 0,134 IMT seseorang dengan nilai $T_{\text {hitung }}>T_{\text {tabel }}(2,429>2,002)$ atau $p<0,05$ dan menurunkan 1,163 persentase lemak total tubuh seseorang dengan nilai $T_{\text {hitung }}>T_{\text {tabel }}(8,691>2,002)$ atau $p<0,05$ serta meningkatkan 0,003 aktivitas fisik seseorang dengan nilai Thitung $>T_{\text {tabel }}(3,333>2,002)$ atau $p<0,05$.

\section{DISKUSI}

Hubungan Indeks Massa Tubuh dengan Persentase Lemak Total Tubuh

Berdasarkan penelitian Ranasinghe tahun 2013 di Sri Lanka pada 1114 subjek usia 18-83 tahun ditemukan hubungan positif yang kuat dan bermakna antara IMT dengan persentase lemak total tubuh pada perempuan. Didukung hasil penelitian yang dilakukan oleh Bohn, et al. tahun 2015 pada 3327 anak dan remaja di Jerman menunjukan bahwa terdapat hubungan positif yang signifikan antara IMT dan persentase lemak total tubuh. Hubungan ini dipengaruhi oleh faktor usia dan jenis kelamin, dimana ketika wanita memasuki masa pubertas terjadi peningkatan massa lemak sehingga massa lemak wanita lebih tinggi daripada pria yang nantinya akan mempengaruhi IMT. Didukung hasil studi 
pada remaja menunjukkan bahwa IMT dan persentase lemak total tubuh memiliki korelasi yang baik hanya pada persentil IMT tertinggi, sedangkan pada persentil yang lebih rendah, korelasi dapat dianggap terbatas. ${ }^{[20]}$ Analisis ini menemukan bahwa IMT berkorelasi dengan cara yang sama dengan lean mass seperti halnya dengan lemak tubuh. Hubungan antara IMT dan persentase lemak total tubuh sebagian dijelaskan oleh hubungan relatif massa lemak total tubuh terhadap total berat badan. [21]

Penambahan massa lemak total tubuh akan menghasilkan peningkatan bertahap persentase lemak total tubuh. Akumulasi lemak dalam tubuh yang sehat umumnya disertai dengan respon kompensasi dari sistem musculoskeletal yang bertindak melalui mechanoreceptor di otot dan tulang agar lebih mudah beradaptasi dalam mengatasi beban mekanik yang meningkat ${ }^{[22]}$ sehingga merangsang adipokin. Adipokin adalah sel lemak yang bekerja secara otokrin, parakrin dan endokrin[23] yang bertindak sebagai pembawa pesan dan mengatur adiposit di dalam timbunan lemak, otot, ${ }^{[24]}$ dan tulang, ${ }^{[25]}$ jika akumulasi lemak tubuh melebihi kompensasi, menyebabkan terjadinya peningkatan respon muskuloskeletal yang akan mengubah proporsi massa lemak total, lean mass dan tulang.

\section{Hubungan Indeks Massa Tubuh dengan Volume Oksigen Maksimal}

Berdasarkan penelitian yang dilakukan oleh Alamsyah, Hestiningsih, dan Saraswati tahun 2017 pada 30 siswi AMU ditemukan hubungan bermakna antara IMT dengan $\mathrm{VO}_{2}$ maks. Sejalan dengan penelitian yang dilakukan Mexitalia, et al. tahun 2012 disebutkan bahwa terdapat hubungan korelasi negatif yang signifikan antara $\mathrm{VO}_{2} \mathrm{maks}$ terhadap IMT. Hal tersebut karena IMT dapat digunakan untuk mengukur komposisi tubuh dan dapat mengklasifikasikan kategori tubuh seseorang. Didukung oleh penelitian yang dilakukan oleh Gonçalves, et al. tahun 2014 dengan subjek sebesar 4,649 siswi ditemukan bahwa perempuan dengan IMT di atas 75 persentil memiliki peluang meningkatnya 2.8, 2.5 dan 11,8 kali lipat pada trigliserida, HDL, dan insulinemia yang akan menyebabkan terjadinya peningkatan 4,7 - 5,3 kali lipat risiko kardiovaskuler dan penurunan $\mathrm{VO}_{2}$ maks dibandingkan dengan yang di bawah 75 persentil.

Penelitian sebelumnya telah menyatakan bahwa faktor fisiologi memainkan peran penting dalam penurunan konsumsi oksigen pada individu dengan indeks massa tubuh yang tinggi. [28] Pada tahun 2011 Masomeh melaporkan bahwa $\mathrm{VO}_{2}$ maks paling rendah pada individu obesitas, diikuti dengan overweight, normal dan underweight. Hal tersebut karena pada obesitas terjadi peningkatan serat otot tipe II dan penurunan serat otot tipe I yang memiliki efek penting terhadap berkurangnya ambilan oksigen, dimana pada obesitas terjadi peningkatan rantai myosin isoform IIx (IIb) mRNA. Dengan demikian, serat tipe II dapat mengakibatkan adanya sekat lemak pada penyimpanan dalam otot rangka (trigliserida intramuskuler) atau jaringan adiposa dan diikuti oleh penurunan oksidasi dalam otot rangka.[30] Pada penelitian Mrad, et al., tahun 1992 melaporkan bahwa dengan pemberian makanan berlemak tinggi pada hewan pengerat memiliki massa tubuh paling besar dan serat tipe I yang jauh lebih sedikit. Penurunan oksidasi lemak seluruh tubuh juga telah diamati pada individu dengan serat tipe II yang lebih banyak. Hal tersebut terlihat bahwa otot rangka dari individu yang obesitas jauh lebih rendah dalam hal kapasitas oksidatif dan kandungan mitokondria serta memiliki peningkatan konsentrasi lipid intraseluler yang terkait dengan resistensi insulin. Dengan demikian, penurunan serat otot tipe I dan peningkatan serat otot tipe II menyebabkan terjadinya penurunan dalam hal ambilan oksigen oleh otot yang aktif[32]

\section{Hubungan Persentase Lemak Total Tubuh dengan Volume Oksigen Maksimal}

Pada penelitian yang dilakukan oleh Murbawani tahun 2017 di SMAN 1 Semarang pada 40 remaja putri usia

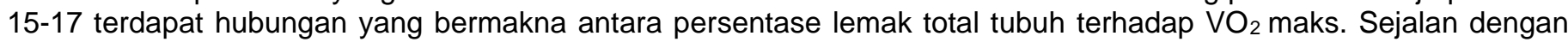
penelitian yang dilakukan oleh Mondal and Mishra (2017) menunjukkan adanya korelasi negatif yang kuat antara persentase lemak total tubuh dan $\mathrm{V}_{2}$ maks. Hal ini sesuai dengan hasil analisis yang menyatakan bahwa peningkatan persen lemak tubuh dapat menurunkan tingkat $\mathrm{VO}_{2}$ maks seseorang. ${ }^{[5]}$

Sejumlah besar lemak tubuh memberikan beban yang tidak baik pada fungsi pernapasan jantung dan ambilan oksigen oleh otot-otot kerja yang aktif sehingga terjadinya penurunan suplai oksigen pada otot-otot yang bekerja akibat peningkatan persentase lemak total tubuh.[17] Deposit lemak yang tidak proporsional menyebabkan sistem muskuloskeletal gagal untuk memperoleh jumlah oksigen yang cukup selama melakukan aktivitas sehingga terjadi penurunan ambilan oksigen yang digunakan untuk metabolisme intrasel, terutama sel-sel muskuloskeletal. Oleh sebab itu, peningkatan persentase lemak total tubuh akan berdampak terhadap penurunan $\mathrm{VO}_{2}$ maks. ${ }^{[33]}$

\section{Aktivitas Fisik dengan Volume Oksigen Maksimal}

Berdasarkan penelitian yang dilakukan oleh Murbawani tahun 2017 di SMAN 1 Semarang pada 40 remaja putri usia 15-17 tahun diketahui bahwa terdapat hubungan yang bermakna antara aktivitas fisik terhadap $\mathrm{VO}_{2}$ maks. Didukung hasil studi epidemiologi diketahui bahwa adanya korelasi positif antara pola aktivitas fisik terhadap $\mathrm{VO}_{2} \mathrm{maks}$ terkait dengan kesehatan[34].

Respon tubuh terhadap aktivitas fisik merupakan hasil respon koordinasi sistem organ, termasuk jantung, paru, pembuluh darah perifer, otot, dan sistem endokrin. Semakin banyak massa otot yang terlibat dalam aktivitas fisik maka semakin besar kontribusi pompa otot pada vena dan semakin bertambah jumlah mitokondria yang aktif. Oleh sebab itu, peningkatan massa otot sangat berpengaruh terhadap peningkatan curah jantung dan tingkat $\mathrm{VO}_{2} \mathrm{maks}^{\text {[ }}{ }^{[5]}$

Aktivitas fisik juga meningkatkan VO2 maks dengan cara meningkatkan curah jantung, volume sekuncup yang tinggi, dan meningkatkan perbedaan oksigen A-V, sehingga berdampak terhadap peningkatan $50 \%$ VO2 maks dan sisanya terjadi peningkatan ekstraksi oksigen oleh otot yang bekerja. Selain itu, juga diikuti pembesaran bilik jantung, peningkatan kepadatan kapiler, peningkatan jumlah mitokondria, dan hipertrofi serat otot. ${ }^{[36]}$ 


\section{Hubungan Aktivitas Fisik dengan Indeks Massa Tubuh}

Berdasarkan penelitian yang dilakukan oleh Tomarere menunjukan bahwa terdapat hubungan bermakna antara tingkat IMT dengan aktivitas fisik, dimana kategori obesitas lebih banyak berada pada tingkat aktivitas fisik yang rendah ${ }^{[37]}$. Sejalan dengan penelitian yang dilakukan Nasr, et al., tahun 2018 menunjukkan bahwa ada hubungan yang kuat antara aktivitas fisik reguler dan IMT normal, Didukung hasil studi kohort prospektif yang dilakukan di Boston didapatkan kegiatan aktivitas fisik yang setara dengan satu jam sehari dapat mempertahankan berat badan yang stabil pada wanita yang berada dalam kisaran berat badan normal. Didukung oleh hasil di mana terdapat hubungan yang kuat antara olahraga dengan IMT ideal. ${ }^{[39]}$

Aktivitas fisik dapat membantu dalam mempertahankan IMT dengan cara membakar kalori dan membangun otot. Beberapa hasil penelitian juga memperlihatkan adanya korelasi negatif antara aktivitas fisik dan IMT [40], yang mana pada penelitian Pitsavos, et al., tahun 2008 menunjukan bahwa individu yang melakukan aktivitas secara teratur minimal 30 menit per hari selama lima hari per minggu akan memiliki IMT yang lebih rendah sekitar 25,9 kg/m2, dibandingkan dengan individu yang kurang aktif sekitar $26,7 \mathrm{~kg} / \mathrm{m} 2$. Hal tersebut karena aktivitas fisik yang dilakukan secara teratur dalam waktu 30 menit dapat membakar membakar kalori sebesar 3,2 kkal/menit. ${ }^{[42]}$

Menurut penelitian Mayer, et al., tahun 1956 mengenai hubungan antara asupan kalori, berat badan, dan pekerjaan fisik pada populasi pria industri di Benggala Barat (India) yang meliputi berbagai macam aktivitas fisik, dari ringan hingga berat. Hal tersebut menunjukan bahwa pembakaran kalori lebih besar pada pekerja yang melakukan aktivitas fisik tingkat sedang hingga tinggi dibandingkan dengan mereka yang melakukan aktivitas fisik ringan. Hal tersebut Karena energi yang dikeluarkan lebih banyak dibandingkan dengan energi yang dikonsumsi sehingga menyebabkan penurunan berat badan. ${ }^{[43]}$

Aktivitas fisik berat juga menunjukkan kontrol nafsu makan jangka pendek yang lebih baik. Didukung oleh hasil dari studi crossectional menunjukkan bahwa aktivitas fisik secara signifikan meningkatkan postprandial PYY (peptida YY), GLP-1 (Glucagon like peptide 1), dan polipeptida pankreas pada orang dewasa dengan berat badan normal, Hal tersebut karena aktivitas fisik dapat memicu perubahan fisiologis dalam sekresi hormon, yang dapat membantu mengendalikan nafsu makan dan berat badan. ${ }^{[43]}$

\section{Hubungan Aktivitas Fisik dengan Persentase Lemak Total Tubuh}

Berdasarkan penelitian yang dilakukan oleh Amelia (2014) menunjukan terdapat korelasi negatif yang bermakna antara aktivitas fisik dengan persen lemak total tubuh. Didukung oleh penelitian yang dilakukan oleh Rahmat, et al., tahun 2017 pada 44 subjek wanita di kota malang menunjukan bahwa terdapat korelasi negatif bermakna aktivitas fisik dengan persentase lemak. Beberapa penelitian di Asia juga menunjukan bahwa terdapat korelasi negatif antara aktivitas fisik dengan obesitas. ${ }^{[46]}$ Penelitian ini sejalan dengan hasil analisis yang menyatakan bahwa semakin tinggi pengeluaran energi melalui aktivitas fisik maka persen lemak total tubuh akan semakin rendah, dimana dengan melakukan aktivitas fisik maka akan meningkatkan metabolisme tubuh dan peningkatan pemakaian cadangan lemak tubuh yang diubah menjadi energi.[47]

Menurut penelitian Crichton dan Alkerwi tahun 2015 menyebutkan bahwa 1 jam per hari melakukan aktivitas fisik sedang akan membuat seseorang memiliki tingkat trigliserida yang rendah. Trigliserida adalah bentuk simpanan utama asam lemak yang tersusun dari trigliserol dan tiga asam lemak.[49] Pada saat melakukan aktivitas fisik terjadi pergerakan otot yang mengakibatkan adanya pemecahan trigliserida pada jaringan adiposa menjadi asam lemak bebas yang nantinya diubah menjadi energy. ${ }^{[50]}$

\section{Hubungan Indeks Massa Tubuh, Persentase Lemak Total Tubuh, dan Aktivitas Fisik Terhadap Tingkat Volume Oksigen Maksimal}

IMT, persentase lemak total tubuh, dan aktivitas fisik sama-sama mempengaruhi tingkat $\mathrm{VO}_{2}$ maks. IMT dan persentase lemak total tubuh yang normal disertai dengan aktivitas fisik yang baik nantinya akan berdampak pada peningkatan $\mathrm{VO}_{2}$ maks. ${ }^{[51]}$ Berdasarkan penelitian yang dilakukan oleh Mondal and Mishra tahun 2017 diketahui bahwa gaya hidup yang menetap atau aktivitas fisik yang tidak memadai tidak hanya terkait dengan peningkatan persentase lemak total tubuh, dan IMT tetapi juga merupakan penyebab penurunan massa otot relatif. Semakin sedikit massa otot yang terlibat dalam olahraga, semakin sedikit kontribusi pompa otot terhadap aliran balik vena, sehingga penurunan massa otot dapat menurunkan curah jantung dan $\mathrm{VO}_{2}$ maks.

Pada obesitas terjadinya penumpukan lemak dan peningkatan berat badan sehingga menyebabkan keterbatasan peningkatan ventilasi yang mempengaruhi tingkat $\mathrm{VO}_{2}$ maks. Obesitas juga meningkatkan beban kerja kardiovaskuler yang juga mempengaruhi tingkat $\mathrm{VO}_{2}$ maks. ${ }^{[52]}$ Oleh karena itu, aktivitas fisik sehari-hari di usia dini penting dilakukan untuk meningkatkan $\mathrm{VO}_{2}$ maks. Berdasarkan penelitian sebelumnya yang mengkaji hubungan IMT, persentase lemak total tubuh, dan aktivitas fisik pada 5101 mahasiswa dan mahasiswi universitas Andrews menunjukan bahwa mahasiswa dan mahasiswi dengan aktivitas fisik yang baik akan diikuti dengan IMT dan persentase lemak total tubuh yang normal umumnya memiliki tingkat $\mathrm{VO}_{2}$ maks yang lebih baik $(\mathrm{p}<0.001)$. Dalam penelitian ini juga telah mendemontrasikan bahwa mahasiswa yang aktif secara fisik memiliki tingkat $\mathrm{VO}_{2}$ maks secara signifikan lebih tinggi daripada mahasiswa yang tidak aktif secara fisik. ${ }^{[53]}$

Penelitian selanjutnya disarankan untuk meneliti hubungan IMT, persentase lemak total tubuh, aktivitas fisik dan hemoglobin terhadap tingkat $\mathrm{VO}_{2}$ maks pada perempuan.

\section{SIMPULAN}

Terdapat hubungan antara IMT dengan persenatse lemak total tubuh pada remaja putri.Terdapat hubungan antara IMT dengan $\mathrm{VO}_{2}$ maks pada remaja putri. Terdapat hubungan antara persentase lemak total tubuh dengan $\mathrm{VO}_{2}$ maks pada remaja putri.Terdapat hubungan yang bermakna antara aktivitas fisik dengan $\mathrm{VO}_{2}$ maks pada remaja 
putri.Terdapat hubungan yang bermakna antara aktivitas fisik dengan IMT pada remaja putri.Terdapat hubungan yang bermakna antara aktivitas fisik dengan persentase lemak total tubuh pada remaja putri, dan Terdapat hubungan antara IMT, persentase lemak total tubuh dan aktivitas fisik terhadap tingkat $\mathrm{VO}_{2}$ maks pada remaja putri.

\section{DAFTAR PUSTAKA}

1. Mondal H, Mishra SP. Effect of BMI, body fat percentage and fat free mass on maksimal oxygen consumption in healthy young adults. J Clin Diagnostic Res. 2017;11(6):CC17-CC20. doi:10.7860/JCDR/2017/25465.10039

2. Maciejczyk M, Więcek M, Szymura J, Szyguła Z, Wiecha S, Cempla J. The influence of increased body fat or lean body mass on aerobic performance. PLoS One. 2014;9(4):0-5. doi:10.1371/journal.pone.0095797

3. Keteyian SJ, Brawner CA, Savage PD, et al. Peak aerobic capacity predicts prognosis in patients with coronary heart disease. Am Heart J. 2008;156(2). doi:10.1016/j.ahj.2008.03.017

4. RISKESDAS. Riset Kesehatan Dasar. Jakarta Badan Penelit dan Pengemb Kesehat Dep Kesehat Republik Indones. 2013;(Penyakit Menular):103. doi:10.1007/s13398-014-0173-7.2

5. Murbawani EA. Hubungan Persen Lemak Tubuh dan Aktivitas Fisik dengan Tingkat Kesegaran Jasmani Remaja Putri. Bagian Gizi, Fakultas Kedokteran, Univ Diponegoro. 2017;5(2):69-84.

6. Scribbans TD, Vecsey S, Hankinson PB, Foster WS, Gurd BJ. The Effect of Training Intensity on VO2maks in Young Healthy Adults: A Meta-Regression and Meta-Analysis. Int J Exerc Sci. 2016;9(2):230-247.

7. Christou D, Gentile C, DeSouza C, Seals D, Gates P. Fatness Is a Better Predictor of Cardiovascular Disease RiskFactor Profile Than Aerobic Fitness in Healthy Men. Circulation. 2005:1904-1914.

8. Pandit R. Phenomenal effect of body mass index on VO2maks in medical students. Asian J Med Sci. 2017;8(5):80. doi:10.3126/ajms.v8i5.17631

9. Strijk JE, Proper KI, Klaver L, Van Der Beek AJ, Van Mechelen W. Associations between VO2maksand vitality in older workers: A cross-sectional study. BMC Public Health. 2010;10(1):684. doi:10.1186/1471-2458-10-684

10. Dhara S, Chatterjee K. A Study of VO 2 maks in Relation with Body Mass Index ( BMI ) of Physical Education Students. Phys Educ Sci_. 2015;3(6):9-12. doi:10.1111/j.1467-9280.2008.02096.x

11. Mi Na Gim, PT M, Junghyun Choi, PT P. The effects of weekly exercise time on VO 2 maks and resting metabolic rate in normal adults. J Phys. 2016:1359-1363.

12. Badan Penelitian dan Pengembangan Depkes RI. Riset Kesehatan Dasar Departemen Kesehatan Republik Indonesia. Riskesdas. 2007. doi:1 Desember 2013

13. Humayrah W. Faktor Gaya Hidup dalam Hubungannya Dengan Risiko Kegemukan Orang Dewasa Di Provinsi Sulawesi Utara, DKI Jakarta dan Gorontalo. Institudt Pertan Bogor. 2009;113(2).

14. Nuttall FQ. Body mass index: Obesity, BMI, and health: A critical review. Nutr Today. 2015;50(3):117-128. doi:10.1097/NT.0000000000000092

15. Alamsyah, Hestiningsih R, Saraswati LD. Faktor-faktor yang berhubungan dengan kebugaran jasmani pada remaja siswa kelas xi smk negeri 11 semarang. J Kesehat Masy. 2017;5(3):77-86.

16. Sulistiono AA. Prediksi Aktivitas Fisik Sehari-Hari, Umur, Tinggi, Berat Badan Dan Jenis Kelamin Terhadap Kebugaran Jasmani Siswa SMP Di Banjarmasin. kemendikbud. 2014:382-383.

17. Sharkey B. Penerjemah Eri Desmarini Nosution. Kebugaran Dan Kesehatan. 1st ed. Jakarta: Raja Grafindo Persada; 2003. doi:-

18. Ranasinghe C, Gamage P, Katulanda P, Andraweera N, Thilakarathne S, Tharanga P. Relationship between Body mass index (BMI) and body fat percentage, estimated by bioelectrical impedance, in a group of Sri Lankan adults: A cross sectional study. BMC Public Health. 2013;13(1). doi:10.1186/1471-2458-13-797

19. Bohn B, Müller MJ, Simic-Schleicher G, et al. BMI or BIA: Is body mass index or body fat mass a better predictor of cardiovascular risk in overweight or obese children and adolescents? Obes Facts. 2015;8(2):156-165. doi:10.1159/000381227

20. Allison G, Korinek J, Batsis JA, Lopez- F. Accuracy of Body Mass Index to Diagnose Obesity In the US Adult Populatio. 2010;32(6):959-966. doi:10.1038/ijo.2008.11.Accuracy

21. Julie A Pasco, Kara L Holloway, Amelia G Dobbins, Mark A Kotowicz, Lana J Williams and SLB. Body mass index and measures of body fat for defining obesity and underweight: a cross-sectional, population-based study. BMC Obes. 2014:1-7.

22. Kohrt WM, Barry DW SR. Muscle forces or gravity: what predominates mechanical loading on bone? Med Sci Sport Exerc. 2009. doi:10.1249

23. Karundeng $R$, Wangko S. Jaringan Lemak Putih dan Jaringan Lemak Cokelat Aspek histofisiologi. Suplemen. 2014;6(3):8-16.

24. Sainz N, Rodriguez A, Catalan V, Becerril S, Ramirez B, Gomez-Ambrosi J FGL. Administration Favors Muscle Mass Accretion By Decreasing FoxO3a and Increasing PGC-1alpha In Ob/Ob Mice. PLoS One. 2009. doi:10.1371

25. Pasco JA, Henry MJ, Kotowicz MA, Collier GR, Ball MJ, Ugoni AM NG. Serum leptin levels are associated with bone mass in nonobese women. J Clin Endocrinol Metab. 2001.

26. Mexitalia, M., Anam, MS., Uemura, A., Yamauchi T. Komposisi Tubuh Dan Kesegaran Kardiovaskuler Yang Diukur Dengan Harvard Step Test Dan 20m Shuttle Run Test Pada Anak Obesitas. Media Medika Indonesian; 2012.

27. Gonçalves R, Szmuchrowski LA, Damasceno VO, Medeiros ML De, Couto BP, Lamounier JA. Association of body mass index and aerobic physical fitness with cardiovascular risk factors in children**Study conducted at School of Physical Education, Physical Therapy, and Occupational Therapy, Universidade Federal de Minas Gerais, Belo Horizonte, MG. Rev Paul Pediatr.2014;32(3):208-214. doi:10.1016/S2359-3482(15)30012-9

28. Regima SE, Balakrishnan R. Effect of body mass index on the $\mathrm{VO}_{2}$ maks in female AMU students. 2016;3(1):272276. 
29. Masomeh, K. Comparison of physical fitness level among normal weight and obese female university students. Ann Biol Res. 2011;2(3):126-133.

30. Houmard JA, Pories WJ, Dohm GL. Is There a Metabolic Program in the Skeletal Muscle of Obese Individuals? 2011;2011. doi:10.1155/2011/250496

31. Mrad J Abou, Yakubu F, Lin D, Peters JC, Atkinson JB and HJ. Skeletal muscle composition in dietary obesitysusceptible and dietary obesity-resistant rats. Am J Physiol Regul Integr Comp Physiol. 1992;262:684-688.

32. Tallis J, James RS, Seebacher F. The effects of obesity on skeletal muscle contractile function. 2018. doi:10.1242/jeb.163840

33. Signaling RA, Zhao Z, Koltai E. Oxygen Consumption and Usage During Physical Exercise : The Balance Between Oxidative Stress. 2013;18(10):1208-1246. doi:10.1089/ars.2011.4498

34. Despre J-P. Body Fat Distribution and Risk of Cardiovascular Disease. 2012;126:1301-1313. doi:10.1161/CIRCULATIONAHA.111.067264

35. Laxmi, Cc., Udaya, Ib., and Shankar, S.V. Effect of body mass index on cardiorespiratory fitness in young healthy males. 2014;4(2):2-5.

36. Bute SS, Shete AN, Khan ST. A Comparative Study of VO 2 Maks in Young Female Athletes and Non-Athletes. 2016;(December 2014):1-4.

37. Tomarere E. Hubungan tingkat aktivitas fisik dengan lingkar pinggang dan indeks massa tubuh karyawan pusat administrasi FKUI usia 25 - 45 tahun. PS IKO. 2011.

38. Nasr NT, Alqahtani AA, Alkahmous BA, et al. Exercise and Eating Habits in Relation to BMI in Female College Students of Almareefa Colleges in Ad Diriyah. 2018;4(1):1-11. doi:10.15744/2455-7633.4.103

39 Lee IM, Djoussé L, Sesso HD, Wang L BJ. Physical activity and weight gain prevention. Jama. 2010;303:11731179.

40. Kaluski DN, Mazengia GD, Shimony T, Goldsmith R, Berry EM. Prevalence and determinants of physical activity and lifestyle in relation to obesity among schoolchildren in Israel. 2008;12(6):774-782. doi:10.1017/S1368980008002991

41. Pitsavos C, Kavouras SA, Panagiotakos DB, et al. Physical Activity Status and Acute Coronary Syndromes Survival The GREECS ( Greek Study of Acute Coronary Syndromes ) Study. JAC. 2008;51(21):2034-2039. doi:10.1016/j.jacc.2008.01.053

42. Viera AJ, Tuttle L, Olsson E, et al. Effects of physical activity calorie expenditure ( PACE ) labeling: study design and baseline sample characteristics. 2017:1-8. doi:10.1186/s12889-017-4710-0

43. Chaput J, Klingenberg L, Rosenkilde M, Gilbert J, Tremblay A, Sj A. Physical Activity Plays an Important Role in Body Weight Regulation. 2011;2011. doi:10.1155/2011/360257

44. Amelia AS. Hubungan Antara Asupan Energi dan Aktivitas Fisik Dengan Persen Lemak Tubuh Pada Wanita Peserta Senam Aerobik. Progr Stud IImu Gizi Fak Kedokt Univ Diponegoro.2014;3:200-205. https://ejournal3.undip.ac.id/index.php/jnc.

45. Rahmat, Indra C.R, Slamet KRG. Hubungan aktifitas fisik dengan kejadian obesitas pada wanita di kota malang. Univ Negeri Malang. 2017;7:26-32.

46. Suryana, Fitri Y. Hubungan Aktivitas Fisik dengan IMT dan Komposisi Lemak Tubuh. Aceh Nutr J. 2017;2(2):114119.

47. Westerterp KR. Physical activity and physical activity induced energy expenditure in humans: measurement , determinants, and effects. 2013;4(April):1-11. doi:10.3389/fphys.2013.00090

48. Crichton GE, Alkerwi A. Physical activity, sedentary behavior time and lipid levels in the Observation of Cardiovascular Risk Factors in Luxembourg study. Lipids Health Dis. 2015:1-9. doi:10.1186/s12944-015-0085-3

49. Robert K, David A, Kathleen M, Peter J, Victor W AP. Biokimia Harper. In: McGraw-Hill T, ed. 29th ed. Toronto, Ontario; 2012:264-266.

50. Thompson D, Karpe F, Lafontan M FK. Physical activity and exercise in the regulation of human adipose tissue physiology. Physiol. 2012;92:157-191.

51. Bryantara OF. Faktor Yang Berhubungan Dengan Kebugaran Jasmani ( $\left.\mathrm{VO}_{2} m a k s\right)$ Atlet Sepakbola. J Berk Epidemiol. 2016;4(2):237-249. doi:10.20473/jbe.v4i2.2016.237

52. Aditya Ghosh DWJ. A Study of VO2maks in Relation to Body Mass Index before and After Exercise in Healthy Young Adults. Dep Physiol. 2017;05(04):20290-20293. doi:https://dx.doi.org/10.18535/jmscr/v5i4.89

53. Pribis $P$, Burtnack CA, Mckenzie SO, Thayer J. Trends in body fat, body mass index and physical fitness among male and female college students. Nutrients. 2010;2(10):1075-1085. doi:10.3390/nu2101075 